recordings of African music, together with tape recorders, cameras, a stroboconn, and other equipment necessary for ethnomusicological research.

At present, three interdisciplinary research projects are being undertaken by members of the programme: a study of pictorial perception among African, Asian, and European primary school children, generously supported by the National Council for Social Research (Department of Education, Arts and Science) and the Ernest Oppenheimer Memorial Trust; the teaching of English as a second language in African schools; the investigation of prehistoric mining and food-producing communities at Iron Age sites in the Transvaal. A fourth interdisciplinary committee has been formed to plan and execute a series of research projects on Indian communities in the Transvaal.

Further information can be obtained from the Chairman of the African Studies Programme, Department of Social Anthropology and African Government, University of the Witwaterstand, Jan Smuts Avenue, Johannesburg, South Africa.

\title{
Aberdeen University African Studies Group
}

The Aberdeen University African Studies Group (Chairman, Professor J. D. Hargreaves; Secretary, Dr. R. C. Bridges) has been founded as a result of the general growth of academic interest in and relations with Africa to encourage that collaboration among the disciplines which has been a distinguishing mark of post-war African studies. The first number of its Bulletin (February 1967 ) contains notes on major departmental and individual activities and a list of interested persons in the university departments and associated research institutes. A programme of interdisciplinary seminars is planned to approach a single broad theme over a period of two years or so; the theme suggested for the first seminar is 'The 'Transition from Subsistence to Cash Economies in Africa'. It is also hoped to develop library and bibliographical services.

\section{A Study Centre for African Religions: Lovanium University, Kinshasa}

A 'Centre d'études des religions africaines' (CERA) has been created in the Faculty of Theology at Lovanium University. The Centre is under the direction of Father Vincent Mulago and has as its object research in traditional and modern African religions.

\section{'The Scolma Directory of Libraries and Special Collections on Africa'}

A second edition of this Directory (see Africa, April i 964, p. 170) compiled by Mr. Robert Collinson, has now been published by Crosby Lockwood \& Son Ltd., 26 Old Brompton Road, London, S.W. 7, price 35 s. The contents are arranged alphabetically by name of place and include university and public libraries, missionary societies, African studies institutes, and private collections containing published and unpublished materials on Africa. Some fifteen libraries have been added to the new edition and many of the contributors have taken the opportunity to amplify their earlier information.

\section{'The Journal of Religion in Africa'}

THrs new international quarterly journal, which is to begin publication early in 1967 , will be devoted to the scientific study of the forms and history of religion (whether Christian, Muslim, traditional or otherwise) within the African continent, and in particular in subSaharan Africa. It will include articles, short notes and reviews, and bibliographical material and instrumenta studiorum will be a specially prominent feature. The languages used will be English and French. The Editorial Board will consist of specialists from universities in 